\title{
Nest success and conservation status of the Blue Swallow Hirundo atrocaerulea in Swaziland
}

\author{
ARA MONADJEM, RICHARD C. BOYCOTT, KIM ROQUES, RAY GAMA and \\ DAVID GARCELON
}

\section{Summary}

The Blue Swallow Hirundo atrocaerulea is a globally threatened species endemic to sub-Saharan Africa. The total population breeding south of the Limpopo River (i.e. in South Africa and Swaziland) probably numbers around 100 pairs. A significant proportion of these birds breed in Swaziland, but to date little has been published on this population. Suitable breeding habitat has been reduced significantly in the country in recent decades, due mostly to afforestation with exotic timber plantations, with urbanization playing a lesser role. In Swaziland, breeding sites are restricted to grasslands above $1,200 \mathrm{~m}$, but mostly above $1,300 \mathrm{~m}$. Timing of egg laying is bimodal indicating double brooding. The number of nests initiated in a season is weakly correlated with rainfall in preceding months. Nests were built predominantly in disused antbear Orycteropus afer burrows, with smaller numbers in natural sinkholes. Mean clutch size was 2.80 , and $61 \%$ of eggs laid resulted in fledged offspring. Mean productivity was 1.30 fledglings per pair per nest attempt. These figures suggest that breeding success is not currently being reduced in Swaziland. The minimum total population currently thought to be breeding in Swaziland is 1o pairs, but this is based on intensive studies of only part of the suitable range. It is recommended that a complete survey be conducted covering the entire range of the species in Swaziland.

\section{Introduction}

The Blue Swallow Hirundo atrocaerulea is endemic to sub-Saharan Africa with breeding populations restricted to montane grasslands of southern and south-central parts of the continent (Keith et al. 1992). Most birds apparently migrate to the shores of Lake Victoria during the non-breeding season (Evans et al. 2002).

During the breeding season, the distribution of the Blue Swallow appears to be determined by two factors: foraging habitat and suitable nest-sites. Blue Swallow habitat consists typically of rolling, open primary grassland with thick short grass (Allan et al. 1987), while nests are always placed in subterranean holes (Tarboton 2001). Foraging appears to take place predominantly in wetlands, such as upper catchments of rivers, interspersed within the grasslands (S. Evans pers. comm.). Grasslands without patches of wetland do not support breeding populations of Blue Swallow (Evans et al. 2002).

A complete census of this species has never been conducted, but in 1998 the global breeding population was estimated to be about 2,000 pairs or 4,000 adult birds (BirdLife International 2000), with the largest breeding populations thought to occur in the highlands of Zimbabwe, Malawi and Tanzania (Evans et al. 2002). The latest estimate suggests that the current breeding population numbers only 1,500 pairs, and is in decline (Evans et al. 2002). 
The Blue Swallow is listed as globally Vulnerable (BirdLife International 2000), but the South African and Swaziland population is Critically Endangered (Barnes 2000, Monadjem et al. 2003). The primary threat to this species is habitat degradation and, in particular, afforestation of its grassland habitat with exotic timber plantations (Tarboton 1994, Allan et al. 1997, Snell 1988).

The South African birds have recently been censused and total 82 pairs (Evans et al. 2002). The Swaziland birds form part of the South African-Swaziland subpopulation, but have not been fully censused. The first published breeding record of Blue Swallow in Swaziland is from the 1950s (Tucker 1957), while a preliminary survey of its distribution was conducted in the mid-1980s (Allan et al. 1987). Between 4 and 8 pairs are known to have bred regularly over the past two decades at Malolotja Nature Reserve in the north-west of the country (Boycott and Parker 2003, Monadjem et al. 2003). The total number of breeding pairs in Swaziland has been estimated at 20-22 (Monadjem et al. 2003). Therefore, the South African-Swaziland subpopulation probably numbers about 100 pairs.

Blue Swallows build a cup-shaped nest that consists of mud and grass, usually attached to the roof of an underground hole (Snell 1963). In Swaziland, disused antbear Orycteropus afer burrows are commonly used for nesting (Boycott and Parker 2003). Nesting density in South Africa has been documented at between 1 pair in 52 ha and I pair in 300 ha (Allan et al. 1987). This species is known to double-brood in southern Africa, the first brood usually being raised in November-December and the second in January-February (Snell 1963, 1969). A mean of about 2.8 eggs are laid per clutch (Earle 1987, Keith et al. 1992), with a mean productivity of 1.33 fledglings per pair per nesting attempt in South Africa (Evans et al. 2002) and 1.63 fledglings per pair per nesting attempt in Zimbabwe (based on the data presented in Snell 1969). Prolonged periods of mist and rain appear to result in nest failure, especially during incubation (Evans and Bouwman 2000). Moult appears to occur almost exclusively on the non-breeding grounds between April and September (Earle 1987), hence moult and breeding do not coincide.

This paper has two objectives: (I) to summarize the breeding biology of the Blue Swallow in Swaziland and (2) to assess the national conservation status of this species.

\section{Methods}

Nests of Blue Swallows were monitored at Malolotja Nature Reserve annually from 1986 to 1997, and in 1999, 2002 and 2003. All known nest-sites were visited each year, usually during November and February, with irregular visits in other months between October and March. New nest-sites were also searched for, but the amount of effort put into finding new nests varied between years. Nest contents were recorded on each visit and, where possible, the fate of the fledglings was determined. Search effort for nests may have varied between years as different observers conducted surveys in different years. However, the monitoring of nests was conducted by a single person (R. C. B.) between 1986 and 1997, and hence search effort probably did not differ significantly among these years. For this reason, all correlations between breeding parameters and climate were restricted to this period.

Intensive surveys of Blue Swallow nest-sites at Malolotja Nature Reserve were conducted in 1999 and 2002. Additionally, during the latter survey, areas beyond the reserve supporting suitable habitat were also visited. 
Laying dates were estimated, to within a week, by the date at which the eggs hatched or chicks fledged, or age of the chicks. The incubation and nestling periods are 15 days and 22 days, respectively (Snell 1979).

Suitable habitat was mapped using ArcView 3.2, a Geographical Information System (GIS). In Swaziland, all Blue Swallow nests were located at altitudes greater than $1,200 \mathrm{~m}$ above sea level (a.s.l.); all but two were above 1,300 $\mathrm{m}$ a.s.l. These two altitudes were, therefore, used to set the lower limit on the distribution of potential habitat within the country. Suitable habitat was therefore determined by mapping grasslands above $1,200 \mathrm{~m}$ and $1,300 \mathrm{~m}$, respectively. The distribution of grasslands was obtained from the Swaziland Vegetation Map (Dobson and Lotter 2006); however, much of this biome has been transformed (mostly to exotic timber plantations) or heavily degraded within the country. These transformed or heavily degraded areas were removed from the distribution map, using the land cover map in Emery (2003). Finally, grassland pockets smaller than 300 ha were excluded from the final map, as they would be unlikely to support viable populations of Blue Swallows (Allan et al. 1987).

\section{Results}

\section{Nest localities and habitat availability}

Suitable habitat for Blue Swallows occurred originally (pre-1950s) in the west of the country. This was never very extensive, and assuming the lower altitude limit of $1,200 \mathrm{~m}$, covered at most less than 170,000 ha (Table 1 ). Much of this area, however, may have been marginal and using the higher altitude limit of 1,300 ha may have better represented suitable habitat, totalling just under 100,000 ha (Table I). Approximately half the original area has been transformed or heavily degraded (Table 1, Figure 1).

The distribution of all Blue Swallow nests ever recorded in Swaziland is shown in Figure 1. The northernmost nest locality was discovered in the 1950s (Tucker 1957) just prior to the grassland area being transformed to exotic timber plantations. There is currently no suitable habitat left in that area (Figure 1 ), and the species no longer breeds there. The remaining nests are all located about $25 \mathrm{~km}$ to the south, at the current northern boundary of suitable habitat. Thirteen old nest-site records (between 1986 and 1998) exist for Malolotja Nature Reserve, and five for surrounding areas beyond the boundary of the reserve (Figures 1 and 2). Recent records (between 1999 and 2003) include 17 nest-sites in Malolotja Nature Reserve and two nest-sites on Sibebe Mountain about $15 \mathrm{~km}$ to the south-east. The species has also been recorded at Mahlangatsha in south-western Swaziland (Parker 1994), and a suspected nest was

Table 1. Areas of potential habitat for Blue Swallows available in Swaziland. Original areas refer to historical distributions of grasslands, while current areas exclude transformed and heavily degraded portions.

\begin{tabular}{|c|c|c|c|c|}
\hline Altitude (m) & $\begin{array}{l}\text { Area (ha) } \\
\text { Original }\end{array}$ & Current & $\begin{array}{l}\text { Per cent } \\
\text { transformed (\%) }\end{array}$ & $\begin{array}{l}\text { Per cent protected } \\
\text { (of original area) }(\%)\end{array}$ \\
\hline$>_{1,200}$ & 167,278 & 81,653 & 48.8 & 6.6 \\
\hline$>_{1,300}$ & 97,809 & 41,064 & 42.0 & 8.7 \\
\hline
\end{tabular}




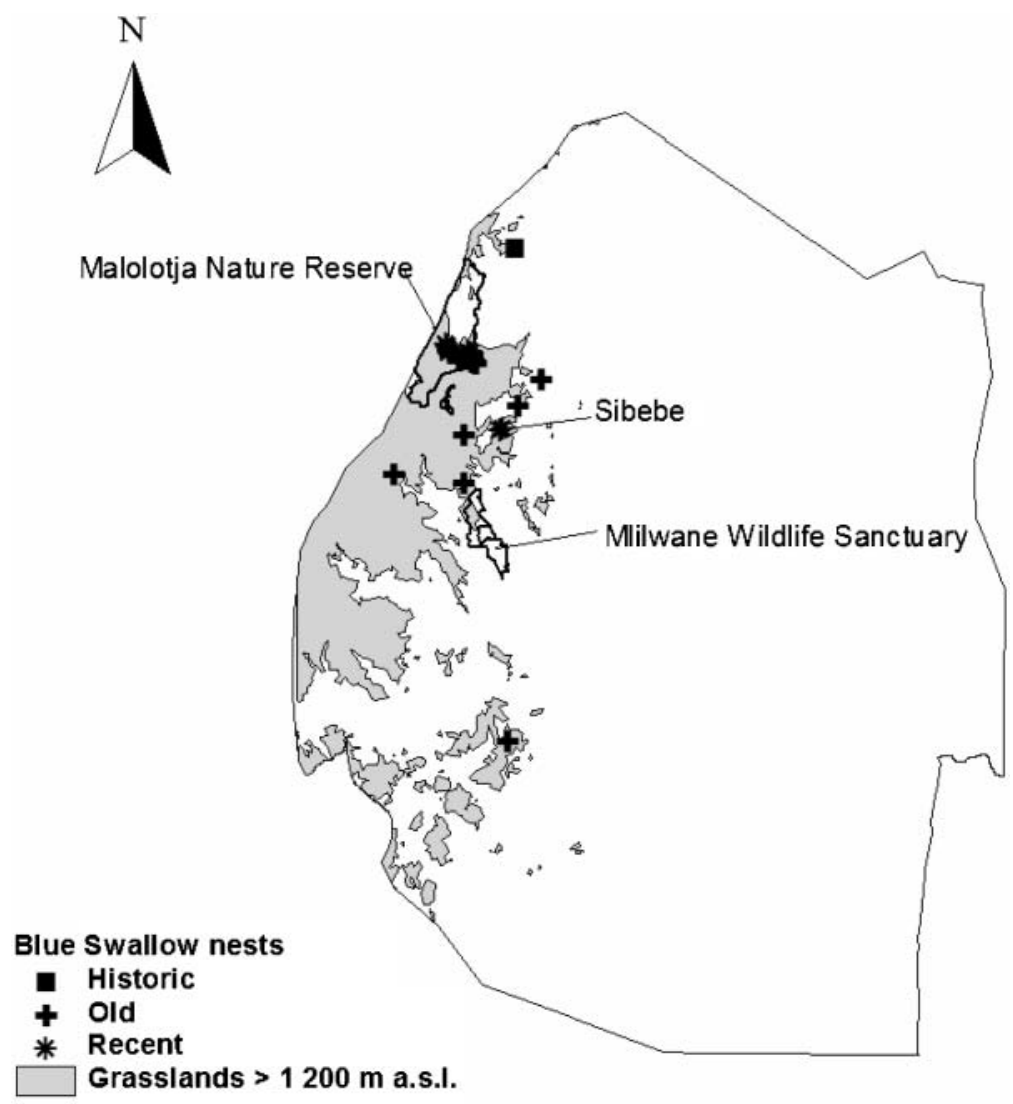

$0 \quad 40 \quad 80 \mathrm{Km}$

Figure 1. Distribution of Blue Swallow nests in Swaziland in relation to the distribution of currently available suitable habitat above $1,200 \mathrm{~m}$. Also shown are the protected areas within the range of the Blue Swallow in Swaziland, as well as the Sibebe mountain breeding site.

located there in the 1991 (V. Parker and R. Boycott pers. obs.; most southerly record on Figure 1 ). The different nest-sites recorded at Malolotja do not necessarily indicate different 'territorial' pairs (see Discussion below).

All recorded nest-sites were situated higher than $1,200 \mathrm{~m}$, a.s.l. and only seven were below $1,300 \mathrm{~m}$ a.s.l. It would appear, therefore, that the nesting habitat of Blue Swallows in Swaziland is not available at altitudes below roughly $1,200 \mathrm{~m}$ a.s.l. This is not a result of habitat degradation or transformation, since extensive protected grassland habitat is available at Malolotja Nature Reserve down to about $900 \mathrm{~m}$ a.s.l.

\section{Nesting season}

In Swaziland, Blue Swallows laid eggs between October and March (Figure 3). Nesting was obviously bimodal, with the first peak between mid-November and mid-December and the second between late January and mid-February (Figure 3). The secondary 


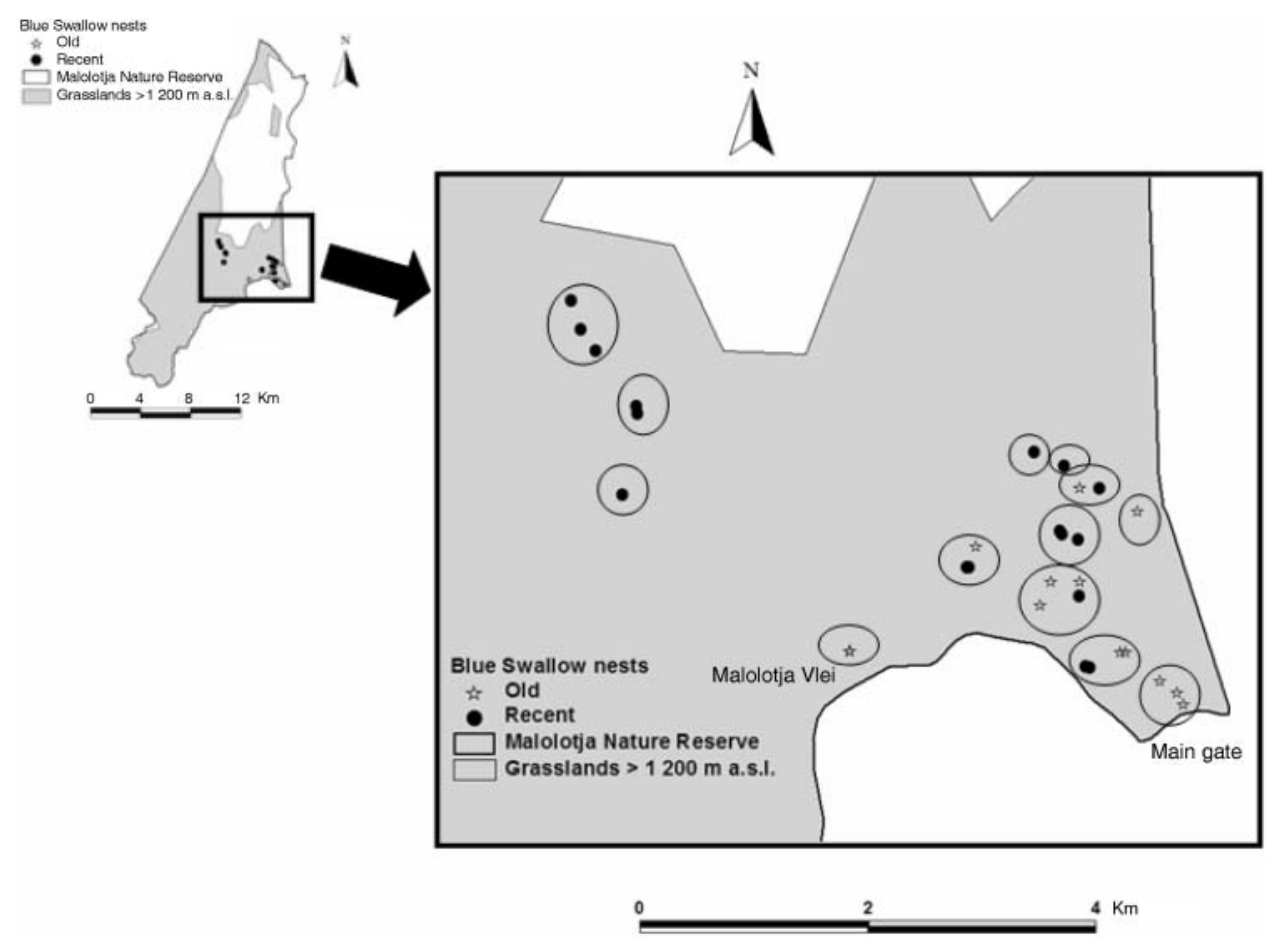

Figure 2. Distribution of old and recent nest-ites at Malolotja Nature Reserve. Also showing are the grasslands above 1,200 $\mathrm{m}$ a.s.l. Circles represent different nesting "territories".

peak in mid-December may be a result of re-laying when nests failed early in the season.

The total number of nests initiated (i.e. nests in which eggs were laid) per season was weakly correlated with annual rainfall (January to December) recorded during the year in which the breeding season commenced $\left(r_{11}=0.415, P=0.158\right)$. A slightly stronger correlation was obtained for the number of nests initiated during the first brood (i.e. nests that were initiated between October to December) and total annual rainfall $\left(r_{11}=0.487, P=0.092\right)$ and rainfall during October $\left(r_{11}=0.448, P=0.125\right)$ (Figure 4 ). These correlations are not significant at the $95 \%$ level, but do approach significance and are thought to be biologically meaningful.

\section{Breeding biology}

In Swaziland, Blue Swallows built nests predominantly in disused antbear holes or natural sinkholes created by underground water flow. Two nests were in man-made holes (Table 2). Of the 15 nests for which information is available, 1o faced in a northerly (including north-east and north-west) direction and three faced due west. Two nests were on flat ground and therefore did not face in any particular direction, while none faced in a southerly direction.

Mean clutch size was $2.80(n=44)$, and did not differ significantly between the first and second breeding attempts $\left(\chi^{2}=0.113, P>0.05\right)$. Hatching success was $68 \%$ (6o of 


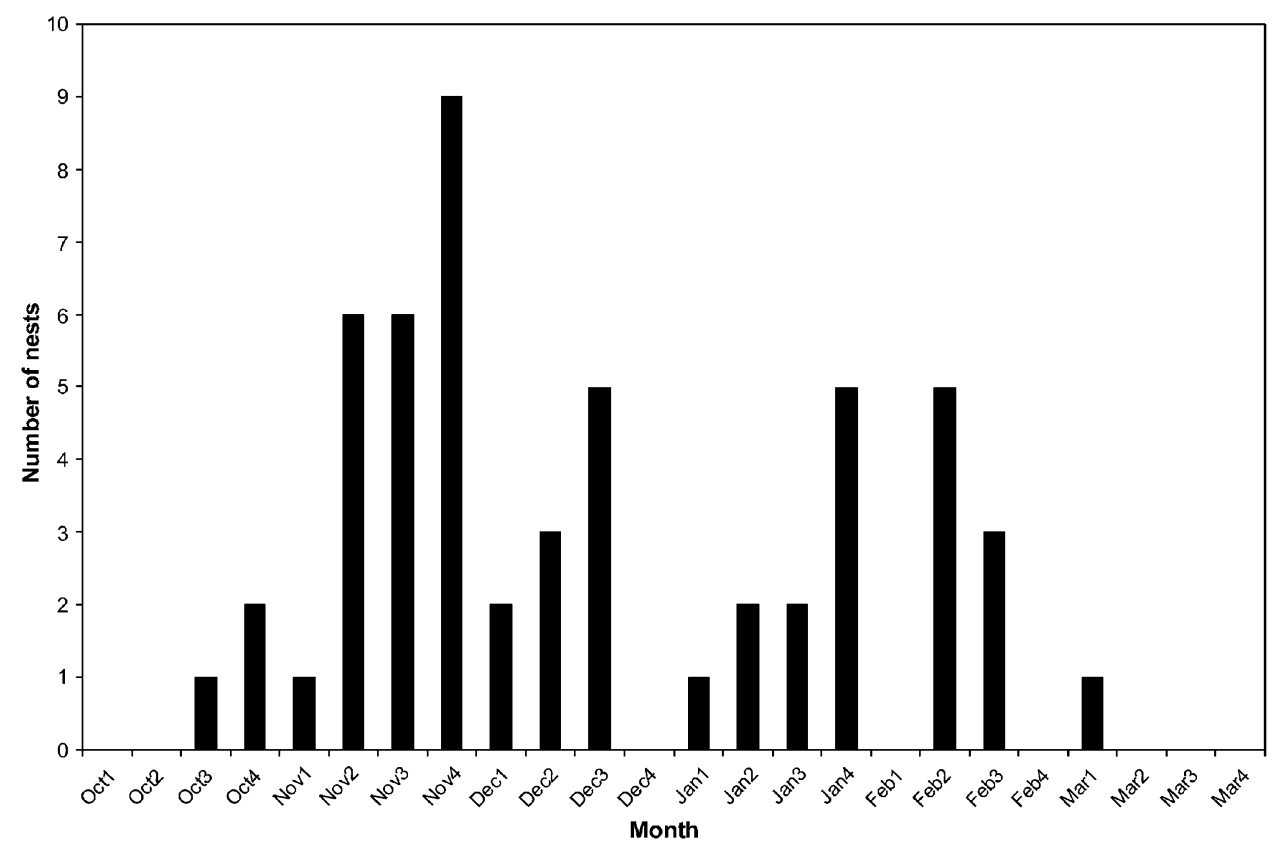

Figure 3. Laying season of Blue Swallow at Malolotja Nature Reserve, obtained from 16 different years between 1986 and 2003. Each month is divided into four "weeks".

88 eggs), and fledging success was $61 \%$ (57 fledglings from 94 eggs laid). Mean productivity was 1.30 fledglings per pair per nesting attempt (57 fledglings from 44 nesting attempts).

Double-brooding was recorded regularly in this population, and on at least two occasions both broods were raised successfully from the same nest. However, since the parents were not individually recognizable, it was not possible to confirm whether the same individuals were involved in both nesting attempts.

The number of fledglings produced per breeding season was correlated neither with rainfall during the preceding year $\left(r_{5}=0.223, P=0.631\right)$ nor with rainfall during the summer months during which breeding took place (i.e. October to March) $\left(r_{5}=-0.581, P=0.227\right)$.

\section{Discussion}

This study provides the first account of the distribution and conservation status of the globally threatened Blue Swallow in Swaziland. Historically, this species may have bred over a large area of western Swaziland. The GIS model of habitat available in Swaziland suggests that over $40 \%$ of habitat suitable for this species has been transformed or heavily degraded in the past 50 years. Although evidence for the contraction of the distribution of the Blue Swallow in Swaziland is limited, at least one breeding population is known to have disappeared. The birds bred in the Pigg's Peak area of Swaziland in the 1950s (Tucker 1957), but were no longer present in the 1980s (Parker 1994). The most serious threat to the Blue Swallow in Swaziland has been afforestation with commercial (exotic) timber plantations that have replaced much of 


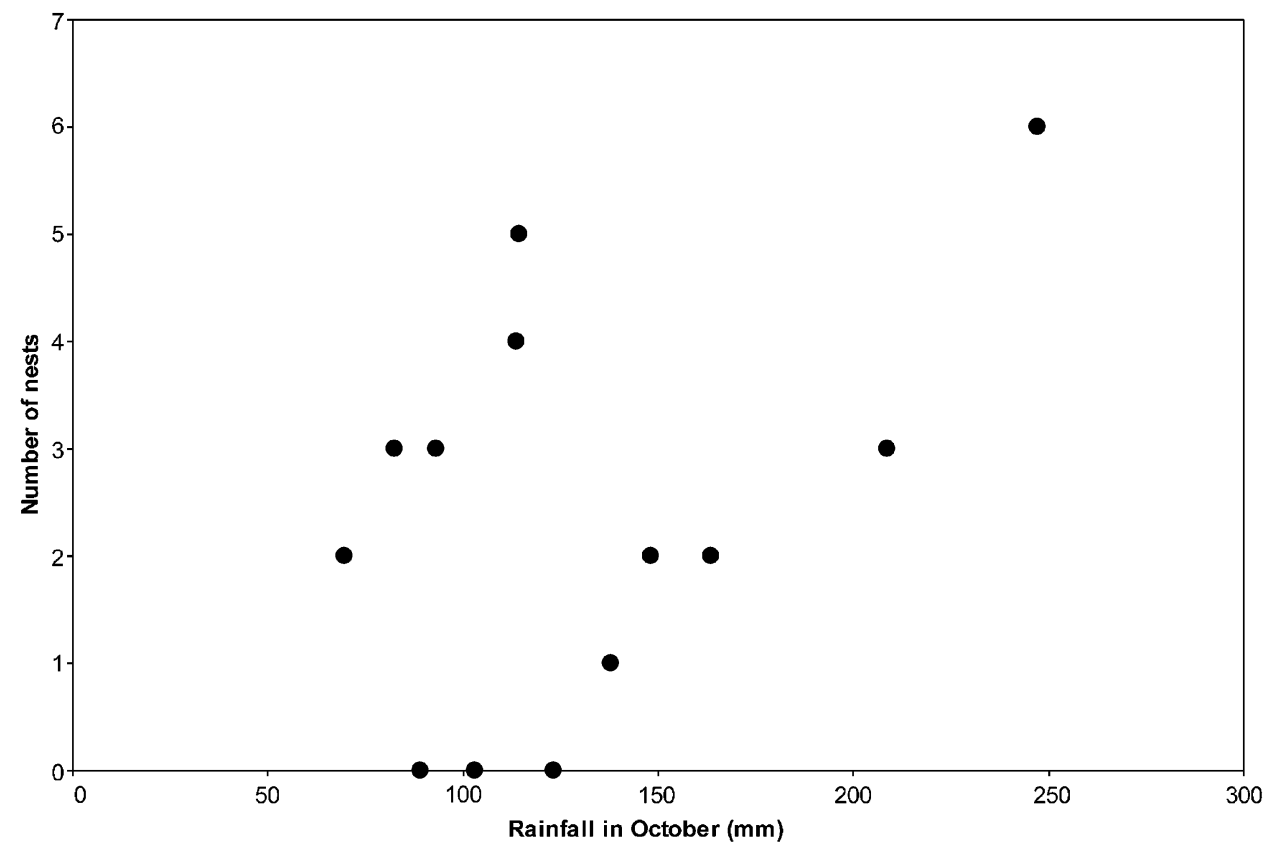

Figure 4. Relationship between number of nests initiated and rainfall during the month of October (first broods only).

Table 2. Type of subterranean hole in which Blue Swallows nested in Swaziland.

\begin{tabular}{llll}
\hline Antbear & Natural sinkhole & Other natural hole & Man-made hole \\
\hline 19 & 14 & 4 & 2 \\
\hline
\end{tabular}

the montane grasslands (Deall et al. 200o). This is also the primary threat to birds in South Africa (Allan et al. 1997).

In Swaziland, breeding was not recorded below $1,200 \mathrm{~m}$, and the majority of nestsites were above $1,300 \mathrm{~m}$. In contrast, Blue Swallows have bred down to $760 \mathrm{~m}$ in KwaZulu-Natal, South Africa (Allan et al. 1987), to the south of Swaziland, while in Zimbabwe breeding is generally confined to grasslands above 1,800 $\mathrm{m}$ (Snell 1969). No doubt this relationship with altitude is mediated by habitat. Suitable foraging and nesting habitat is dependent on temperature and rainfall, both of which are heavily affected by altitude and latitude (Cox and Moore 200o). This finding suggests that efforts to conserve Blue Swallow habitat in Swaziland should target grasslands above $1,300 \mathrm{~m}$.

There is some evidence pointing to local movements of "territorial" pairs within Malolotja Nature Reserve (see Figure 2). The pairs that bred in the 1980 os and early 1990s near the entrance gate of the reserve and in the Malolotja vlei were no longer actively breeding in those areas in the late 1990s or later. However, during the late 1990s several new pairs were discovered to the west of the original area. Whether these pairs had been overlooked, or represent local movement of "territorial" pairs within Malolotja Nature Reserve, is not known. 
Nest-sites most commonly used in Swaziland were antbear burrows, followed by natural sinkholes associated with drainage lines. This is in contrast to the findings of Allan et al. (1987), who reported seven of nine nests located in Swaziland to be in natural sinkholes. This suggests that either there has been a drop in the usage and/or availability of natural sinkholes, or that Allan et al.'s (1987) study overlooked nests in antbear holes.

The bimodal pattern of egg-laying in Swaziland is indicative of double-brooding, which is not unusual in this species (Snell 1969) and has been reported in other Hirundo species in southern Africa (Jackson and Spottiswoode 2004). The timing of egg-laying varied among years, probably reflecting food availability (insects), which in turn is affected by rainfall. The number of nests initiated in a season was weakly but positively correlated with rainfall. Rainfall is known to affect the initiation of breeding in African birds (Vernon 1978), so this relationship is not surprising, but has not previously been reported in the Blue Swallow. Increased rainfall during the nesting period, however, reduces fledging success (Evans and Bouwman 2000). The relationships among timing and amount of rainfall, and timing and nesting success, are likely to be complex and warrant further investigation.

The mean clutch size of Blue Swallow in Swaziland (2.80) closely approximates the figures of 2.64 recorded in South Africa (Evans et al. 2002) and 2.83 in Zimbabwe (Keith et al. 1992). The hatching success of $68 \%$ recorded in this study is rather low, compared with $84 \%$ in Zimbabwe (calculated from data presented in Snell 1969), and with Red-breasted Swallow (79-84\%; Earle 1989). This low hatching success may have been an artifact of the way the data were collected in this study. Nests were not visited daily, and therefore eggs that hatched but whose chicks disappeared before the next visit would have been recorded as unhatched, lowering apparent hatching success. However, fledging success was also low in this study with only $61 \%$ of eggs resulting in the fledging of an offspring. In contrast, 80\% of eggs fledged in Zimbabwe (calculated from data presented in Snell 1969). However, the latter study may have overestimated survival by assigning failed nests as unknown outcome. This is supported by the fact that fledging success in the Red-breasted Swallow was also $60.6 \%$ (Earle 1989).

Mean productivity in this study was 1.30 fledglings per pair per nesting attempt, which is similar to the 1.33 fledglings per pair per nesting attempt recorded in South Africa (Evans et al. 2002) but slightly lower than the 1.63 recorded in Zimbabwe (calculated from data presented in Snell 1969) or the 1.94 recorded in the Red-breasted Swallow (Earle 1989). If breeding success of Blue Swallows at Malolotja Nature Reserve is similar to that at other sites, then this suggests these birds are breeding successfully and that there are currently no factors reducing breeding success.

In Swaziland, the majority of known pairs of Blue Swallows have bred within Malolotja Nature Reserve. The maximum number of nests recorded at Malolotja that were active simultaneously (i.e. eggs were laid) is eight, in 1999, while five nests were active simultaneously in 2002. In all other years, no more than four nests were active at the same time. It would appear, therefore, that up to eight pairs have bred at Malolotja Nature Reserve in recent years. However, over the past two decades, 13 different 'territories' have been recorded here (Figure 2).

In addition, two pairs have bred in recent years on Sibebe Mountain, a site which has been the focus of a community-based conservation project. Hence, up to to pairs are currently known to breed in Swaziland. 
The fate of the five nest-sites located between 1986 and 1998 (Figure 1 ) is not known. Two of the nest-sites were situated on the outskirts of the capital city Mbabane in 1986, and may well have been subsumed by it since. A third site (the most westerly site in Swaziland) was not considered to have been located in suitable habitat (based on vegetation and altitude) and the pair failed to raise any chicks (V. Parker pers. comm.). The two remaining sites are both east of Malolotja Nature Reserve. One of these was checked in 2002, but was not active then. Therefore, one or possibly two of these 'old' nests may still be in use. The status of the Blue Swallow in the area between Sibebe Mountain and Malolotja Nature Reserve is not known. Birds have been seen there in the past 8 years (M. Unwin pers. comm.) but no nests have been found. Similarly, the status of the Blue Swallow in the south-west of the country is also not currently known. Hence, we recommend that a complete survey be conducted covering the entire range of the species in Swaziland.

\section{Acknowledgements}

This is the First Communication of the All Out Africa Research Unit (www.allout.org). We are indebted to Vincent Parker and Glen Slade for finding many of the nests reported here. Sipho Matsebula assisted with field work. Thanks go also to Dr Tony Diamond for valuable comments on an earlier draft of this paper.

\section{References}

Allan, D. G., Gamble, K., Johnson, D. N., Parker, V., Tarboton, W. R. and Ward, D. M. (1987) Report on the Blue Swallow in South Africa and Swaziland. Johannesburg: Endangered Wildlife Trust.

Allan, D. G., Harrison, J. A., Navarro, R. A., Van Wilgen, B. W. and Thompson, M. W. (1997) The impact of commercial afforestation on bird populations in Mpumalanga Province, South Africa: insights from bird-atlas data. Biol. Conserv. 79: 173-185.

Barnes, K. N., ed. (2000) The Eskom Red Data Book of birds of South Africa, Lesotho and Swaziland. Johannesburg: BirdLife South Africa.

BirdLife International (2000) Threatened birds of the world. Barcelona and Cambridge, U.K.: Lynx Edicions and BirdLife International.

Boycott, R. and Parker, V. (2003) Birds of the Malolotja Nature Reserve, Swaziland. Cape Town and Mbabane: Avian Demography Unit \& the Conservation Trust of Swaziland.

Cox, C. B. and Moore, P. D. (200o) Biogeography: An ecological and evolutionary approach. Sixth edition. Oxford: Blackwell Science.

Deall, G., Dobson, L., Masson, P., Mlangeni, N. J., Murdoch, G., Roques, K. G. and Shirley, H. O. A. (2000) Identification of protection-worthy areas in Swaziland. Report to the Ministry of Agriculture and Cooperatives, Mbabane.

Dobson, L. and Lotter, M. (2006) Swaziland vegetation map. In L. Mucina and M. C. Rutherford, eds.. Vegetation map of South Africa, Lesotho and Swaziland.

Earle, R. A. (1987) Measurement, moult and timing of breeding in the Blue Swallow. Ostrich 58 : 182-185.

Earle, R. A. (1989) Breeding biology of the Redbreasted Swallow Hirundo semirufa. Ostrich 6o: 13-21.

Emery, A. (2003) Gathering and analysing appropriate spatial information to define the boundaries of the biodiversity and tourism corridors Mbabane: Swaziland Biodiversity Conservation and Participatory Development Project, Swaziland Environment Authority. 
Evans, S. W. and Bouwman, H. (2000) A preliminary look at the influence of mist and rain on the reproductive success of the Blue Swallow Hirundo atrocaerulea. Ostrich 71: 83-86.

Evans, S. W., Cohen, L., Sande, E., Monadjem, A., Hoffmann, D., Mattison, H., Newbery, P., Ndanganga, K. and Friedmann, Y., eds. (2002) Blue Swallow (Hirundo atrocaerulea) International Action Plan. Final Workshop Report. Johannesburg: Conservation Breeding Specialist Group.

Jackson, H. D. and Spottiswoode, C. (2004) Breeding biology and taxonomy of the Red-breasted Swallow, Hirundo semirufa, in Zimbabwe. Ostrich 75: 5-10.

Keith, S., Urban, E. K. and Fry, C. H. (1992) The birds of Africa. Volume IV. London: Academic Press.

Monadjem, A., Boycott, R. C., Parker, V. and Culverwell, J. (2003) Threatened vertebrates of Swaziland. Swaziland Red Data Book: fishes, amphibians, reptiles, birds and mammals. Mbabane: Ministry of Tourism, Environment and Communications.

Parker, V. (1994) Swaziland bird atlas, 1985-1991. Mbabane: Websters.

Snell, M. L. (1963) A study of the Blue Swallow (Hirundo atrocaerulea). Bokmakierie 15: 4-7.

Snell, M. L. (1969) Notes on the breeding of the Blue Swallow. Ostrich 40: 65-74.

Snell, M. L. (1979) The vulnerable Blue Swallow. Bokmakierie 31: 74-78.

Snell, M. L. (1988) Local extinction of the Blue Swallow at Nyanga. Honeyguide 34: 30-31.

Tarboton, W. (1994) The Blue Swallow: still so precarious. In Vision of wildlife, ecotourism and the environment in South Africa. Johannesburg: Endangered Wildlife Trust.

Tarboton, W. (2001) A guide to the nests and eggs of southern African birds. Cape Town: Struik.

Tucker, B. (1957) Swallows in Swaziland. Bokmakierie 9: 43.

Vernon, C. J. (1978) Breeding seasons of birds in deciduous woodland at Zimbabwe, Rhodesia, from 1970 to 1974. Ostrich 49: 102-115.

ARA MONADJEM

Department of Biological Sciences, University of Swaziland, Private Bag 4, Kwaluseni, Swaziland

RICHARD C. BOYCOTT

P. O. Box 5245, Mbabane, Swaziland

KIM ROQUES

All Out Projects, P. O. Box 132, Mahlanya, Swaziland

RAY GAMA

Swaziland National Trust Commission, P. O. Box 10o, Lobamba, Swaziland

DAVID GARCELON

Institute for Wildlife Studies, P. O. Box 1104, Arcata, California, U.S.A.

Received 17 January 2005; revision accepted 14 September 2005 